International Journal of Physical Sciences and Engineering
Available online at http://sciencescholar.us/journal/index.php/ijpse
Vol. 3 No. 3, December 2018, pages: 77 91
e-ISSN : 2550-6943, p-ISSN : 2550-6951
https://doi.org/10.29332/ijpse.v2n3.233

\title{
Application Design in Determining the Shortest Route Using Tabu Search Algorithm
}

\author{
Lita Alfriany Ndoloe a, Nelci Dessy Rumlaklak ${ }^{\mathrm{b}}$
}

Article history: Received 27 April 2018, Accepted: 30 August 2018, Published: 14 December 2018

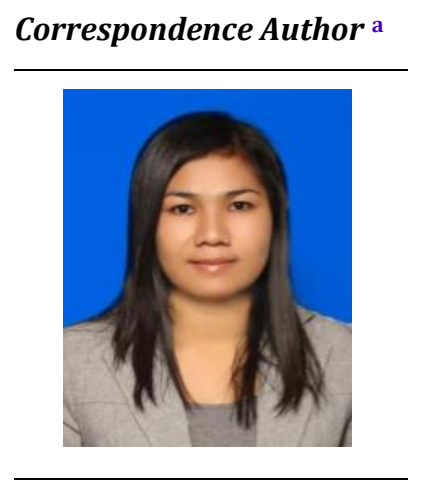

Keywords

Indonesia;

Rote Island;

Tabu search algorithm;

the fastest route;

tourism place;

\begin{abstract}
This research designed a website application using Tabu Search Algorithm. We applied the Queuing method to find the shortest distance. Applications with this algorithm can provide the fastest route in the experiment of searching the shortest distance. We conducted this research by applying the examination in Rote Island, Indonesia. On the island, we examined the shortest distance from a starting point to another tourism place. In another side, this system utilized Google Map services to retrieve data about the distance between locations to another location with driving mode. The Google Maps service application is received in the form of translated JavaScript Object Notation (JSON), in order to be used as data and parameters in executing tabu search algorithms. The system was built using web-based through Hypertext Preprocessor (PHP) programming language, HyperText Markup Language (HTML), and Javascript, so it can be accessed and run by all devices that run the browser.
\end{abstract}

e-ISSN: 2550-6943, p-ISSN: 2550-6951 ๑Copyright 2018. The Author. SS Journals Published by Universidad Técnica de Manabí. This is an open-access article under the CC BY-SA 4.0 license (https://creativecommons.org/licenses/by-sa/4.0/) All rights reserved.

\section{Contents}

Abstract 77

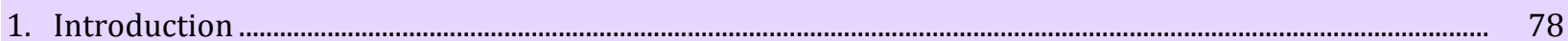

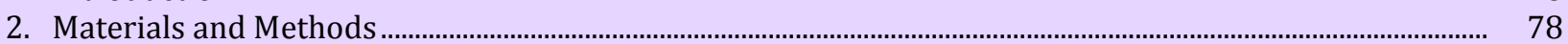

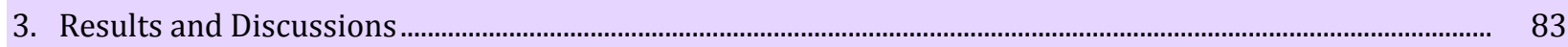

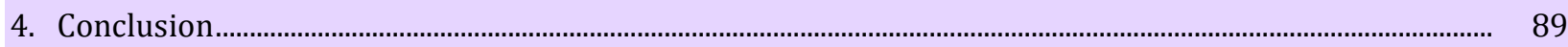

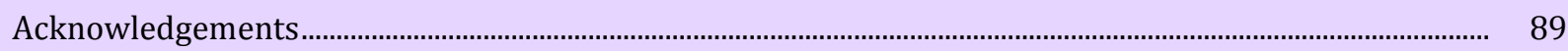

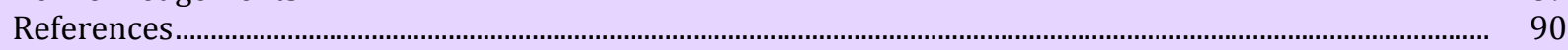

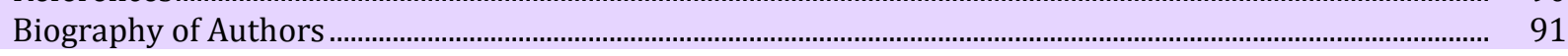

a Politeknik Negeri Kupang, Department of Engineering, Kupang, Indonesia

b Universitas Nusa Cendana, Department of Computer Sciences, Kupang, Indonesia 


\section{Introduction}

Problems that often arise in finding the shortest distance or the fastest route in any area is the lack of information itself. It has also happened in the tourism activity, when people, in this case, tourists, need to find a path to get tourist attractions place or to know the level of a street crowded and the volume of the path. Due to their limited time, the shortest route search is important (Fard \& Akbari, 2013).

Searching the shortest route is to determine the most optimal path, that is the path with the shortest route and the smallest fee. This can be applied by searching all routes altogether through a connected network (Chelouah \& Siarry, 2000). In some applications, it is also helpful to know the shortest paths with two or three additional alternatives, for example, in order to improve the effectiveness of travel information, a driver can get some choices as s/he like based on the need.

Determining routes can use metaheuristic process. It is the method for finding a solution by combining interaction between local searching procedures and higher strategies, in order to create a process that is able to get the local optimal spots, and do a search on space solutions for finding global solutions (Kusumadewi \& Purnomo, 2005). Metaheuristic variants are Simulated Annealing, Genetic Algorithms, Cross Entropy, Particle Swarm Optimation and Tabu Search (Bajeh \& Abolarinwa, 2011). Searching fastest distance and the shortest route, in this research we choose the tourist attraction places at Rote Ndao Regency- Indonesia is applied using Tabu Search since it has shown good performance with functions more than 10 variables (Sarmady, 2012). This algorithm can optimize costs and can produce minimum cost. In the case of our research, Tabu Search algorithm is able to increase the initial solutions through improving procedures.

As have been stated, we applied the system by examining tourism attraction places in Rote Island, Indonesia. Geographically, it is located between 10 degrees $25^{\circ}-11$ degrees south latitude, and 121 degrees 2649 - 123 degrees East longitude. It has a wide choice of tour destinations such as Nemberala Beach, Bo'a Beach, Mando's Beach, Oeseli Beach, Laviti Beach, the Lake of the Dead Sea, Termanu stone, etc. There are many tourists have visited this island. To help tourism development in Indonesia, especially in Rote Island, as well as to examine the application built in finding the shortest route, we conducted this research.

\section{Materials and Methods}

This research has been planned for eight months starting from July until November 2018 at the Kupang State Polytechnic, that is to design included the examining the results of the implementation. They were carried out in the Computer Lab.-electrical engineering - Kupang State Polytechnic. The process was based on data taken from information about road route, that related to tourism place, in Rote island.

Rote Islands also called the Island of Roti, is an Island in East Nusa Tenggara Province, Indonesia. East Nusa Tenggara Province itself is located between 80-120 South latitude and 1180-1250 East longitude, with a land area of $47,349.9 \mathrm{~km}^{2}$ and has a total area of a sea of $200,000 \mathrm{~km}^{2}$. The number of Islands in East Nusa Tenggara province is 566 Islands. 42 Islands have been inhabited while the uninhabited Islands are 524. NTT has got 21 regencies. One of the island, as well as the regency, is Rote (Manafe et al., 2018).

The methods used in this study consists of the following steps. First, we conducted studies on various references libraries related to the research. Topics examined include Tabu Search Algorithm, Graph and the use of Google Maps API. Next, we prepared a database about tourism attractions places in Rote island, which include the name of the tourism objects, etc. After that, we designed application to determine route and distance with the implementation of the Tabu Search algorithm. The last, we examined the application. The steps of our research can be seen in the following figure. 


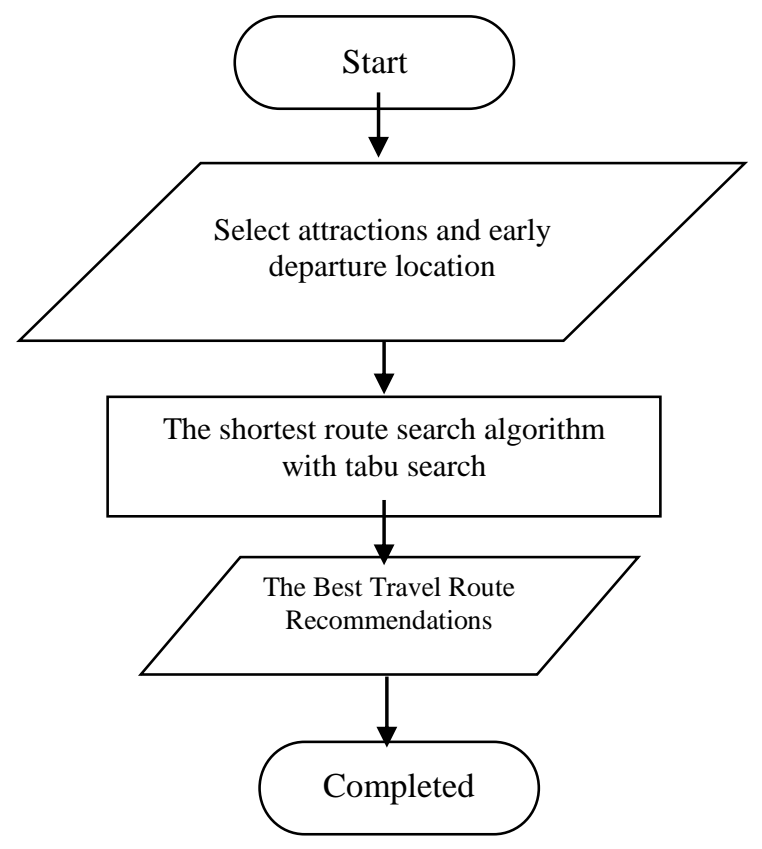

Figure 1. Research Steps

\section{The Steps of Tabu Search Method}

As stated above, we applied tabu search method to determine the shortest route in finding tourism place in Rote Island, Indonesia. The steps of tabu search method are described as follows.

1) Data Collection

The data required for testing algorithms is the data of route and distance as well as tourist sites.

2) Parameters Determination

At this stage, we determined parameters of tabu search, including the number of population of each iteration (N), TabuListMemberCount and itmax_Tabu (maximum iterations of Tabu Search) (See. Munir, 2010).

3) Candidate generation solution of Tabu Search

Candidate generation solution of Tabu Search uses neighborhood selection. Next, we conducted an exchange of neighbor so that the application will appear on the possible ' $n$ ' solutions.

4) The selection of the best solution of candidate solutions

Candidate solutions which are generated are evaluated one by one and will be sorted from the smallest to the largest. The best route will be evaluated whether it can be included in the Tabu List or not. In the process, queue function is added in the determination of the neighborhood.

5) Update Tabu List

The best route from step 4 will be evaluated to know whether they are better than what is in the routes of Tabu List or not. If the route appeared is better than existing routes in the Tabu List, then the route will be included in the tabu List, to replace worse routes in the Tabu List. The best route is to be used for candidate generation solutions on the next iteration. However, if the route generated is not better than an existing route in the Tabu List, then the solution will not be included in the Tabu List and random route generation will be conducted for the exchange of neighbors on the next iteration.

6) Checking the expiration criteria by considering the maximum iteration specified in step 2.

Ndoloe, L. A., \& Rumlaklak, N. D. (2018). Application design in determining the shortest route using tabu search algorithm. International Journal of Physical Sciences and Engineering, 2(3), 77-91. https://doi.org/10.29332/ijpse.v2n3.233 
In General, the steps described in the method of Tabu Search can be seen in Figure 2 below.

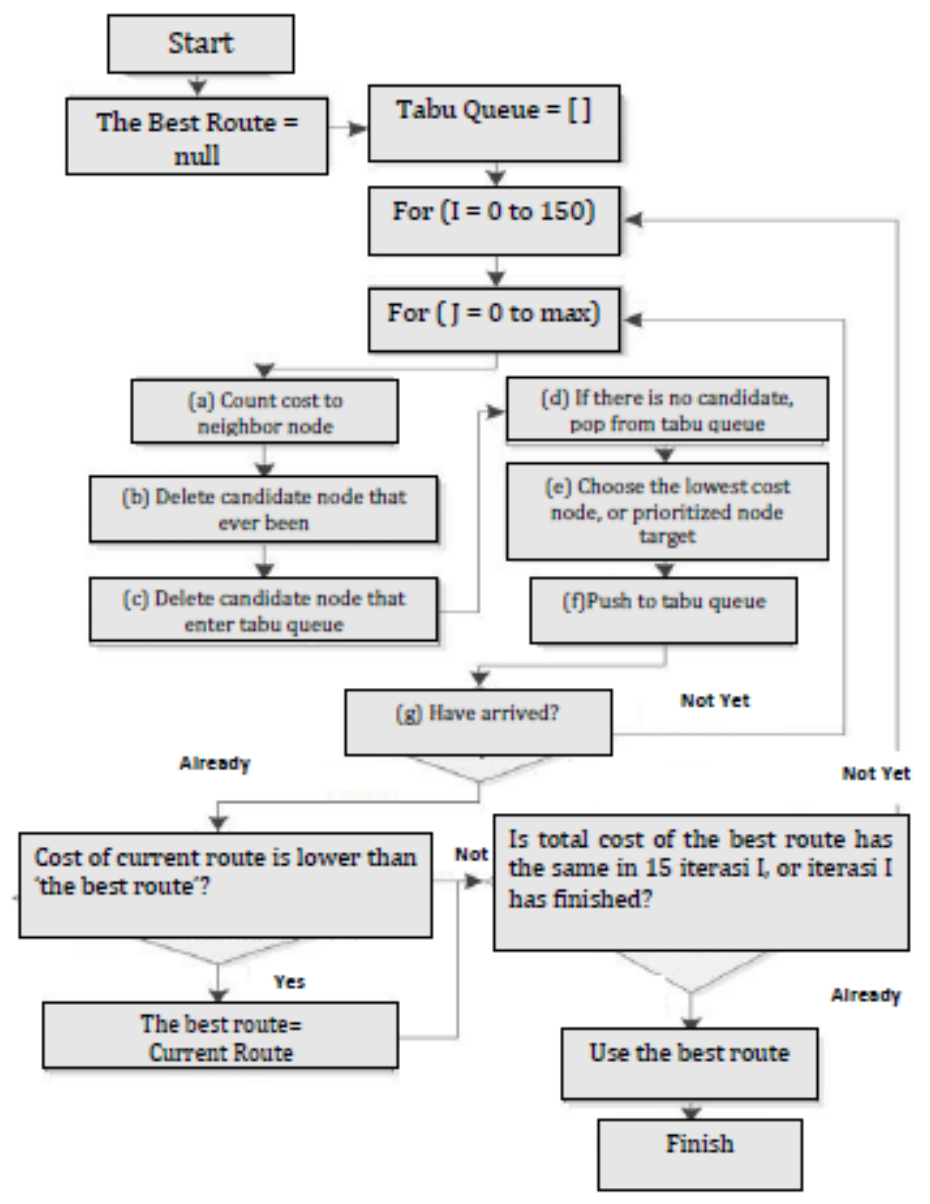

Figure 2. Flowchart Algorithms of Tabu Search (Varita et al., 2014)

\section{The Design of System}

Following is the design of a system that consists (a) input, process, and output of the system, (b) The use of case diagram, (c) The activity diagram, (d) The sequence diagram, and (e) data dictionary.

a) Input, Process, and Output Systems

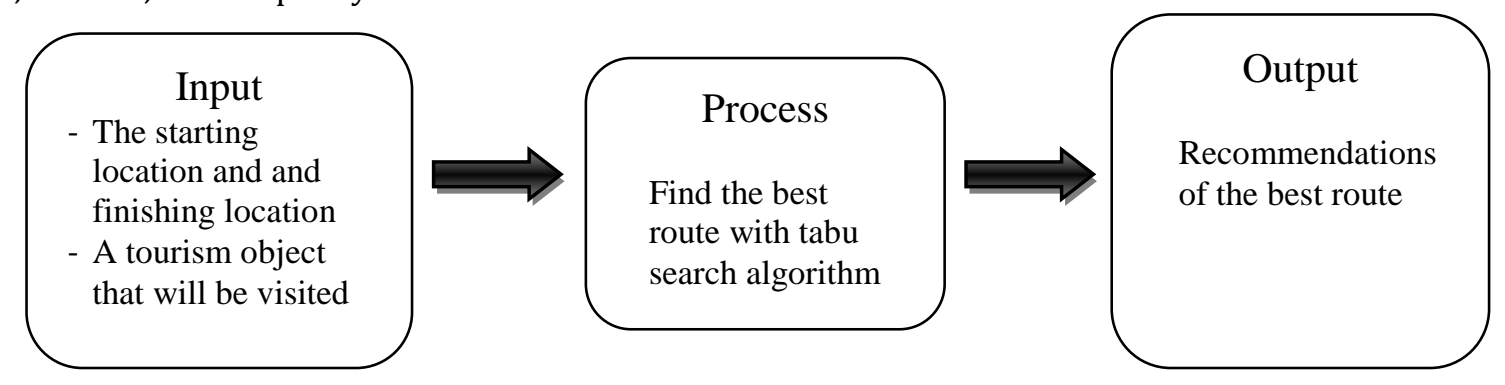

Figure 3. Input, process, and output systems 
On this shortest route search system, the user is expected to enter data about the point of start location and attractions place that would be visited. Next, it will be processed by searching for the best route algorithm with tabu search. Once processed, the user will receive an output in the form of a recommendation of the shortest route for tourism objects selected.

b) Use Case Diagram

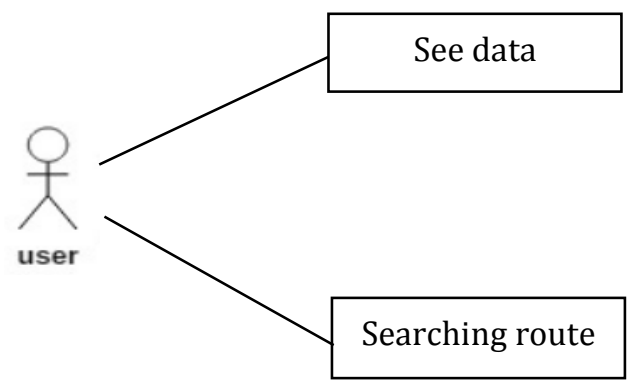

Figure 4. Use Case Diagram

c) Activity Diagram

Activity Diagram of the system is the determination of the route of the trail will be built. Following is the activity diagram is shown in figure 5 .

Ndoloe, L. A., \& Rumlaklak, N. D. (2018). Application design in determining the shortest route using tabu search algorithm. International Journal of Physical Sciences and Engineering, 2(3), 77-91. https://doi.org/10.29332/ijpse.v2n3.233 


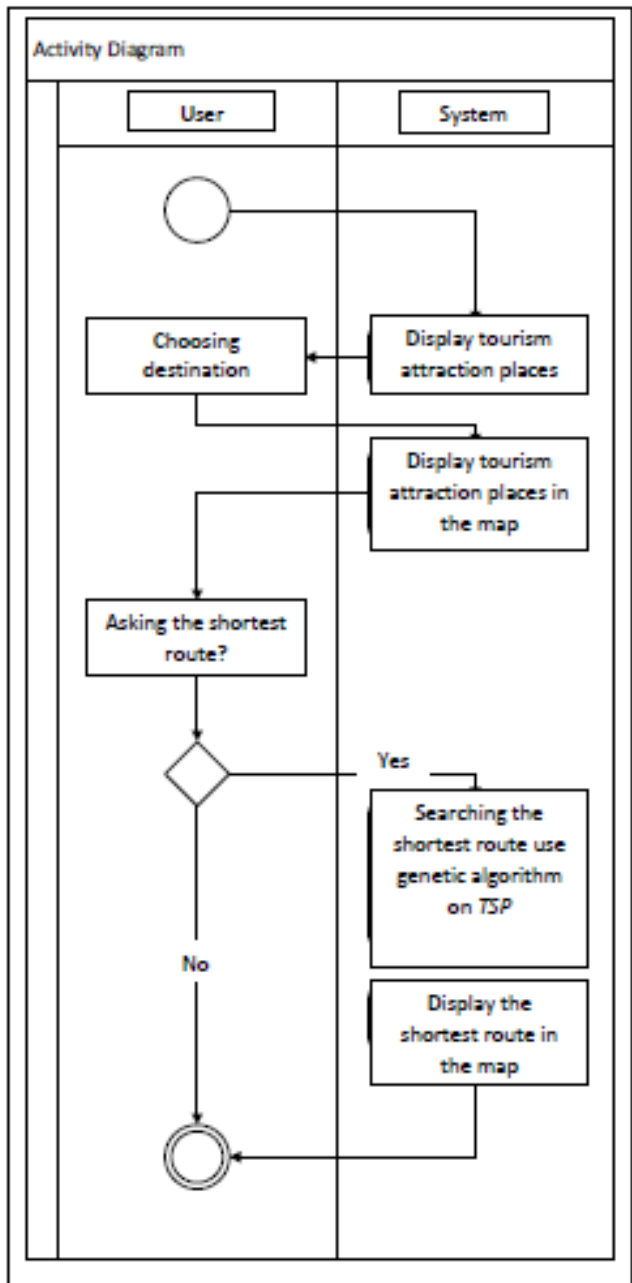

Figure 5. Activity Diagram

d) Sequence Diagram

The sequence diagram in following Figure 6 describes the process of running the system for searching the shortest route.

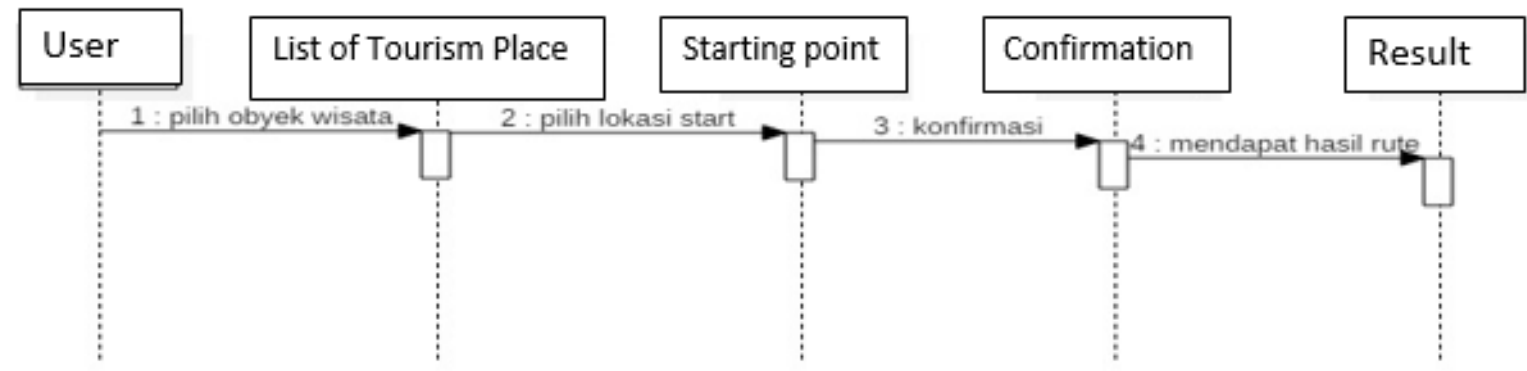

Figure 6. Sequence Diagram 
e) Data of Dictionary

Date of the dictionary is shown on the following tables.

Table 1

Data tables to the tourism object

Table name: objwisata

Primary key: id_obj

Foreign: type_obj

\begin{tabular}{lllll}
\hline No. & Field Name & Type & Size & Description \\
\hline 1 & id_obj & int & 4 & ID tourism \\
2 & name_obj & varchar & 45 & Name of tour destinations \\
3 & kind_obj & varchar & 45 & Type of tour \\
4 & LAT & varchar & 45 & Latitude of coordinates (latitude/longitude) \\
5 & long & varchar & 45 & Longitude coordinates \\
6 & desc_obj & longtext & 500 & Description of tour destinations \\
\hline
\end{tabular}

Table 2

Table Data types of Tourism

Table name: jeniswisata

Primary key: id_kind

\begin{tabular}{lllll}
\hline No. & Field Name & Type & Size & Description \\
\hline 1 & id_kind & varchar & 20 & ID type of tours \\
2 & name_kind & varchar & 45 & Type of tour \\
\hline
\end{tabular}

\section{Results and Discussions}

Based on the design of the application we have developed, it is explained that the system is built to determine the route of tourism place (Suyanto, 2010). Therefore we listed tourism attractions/tourism places that located in Rote Ndao Regency, Indonesia. These are objects that become tourist destinations.

Table 3

The list of Tourism Places in Rote Island

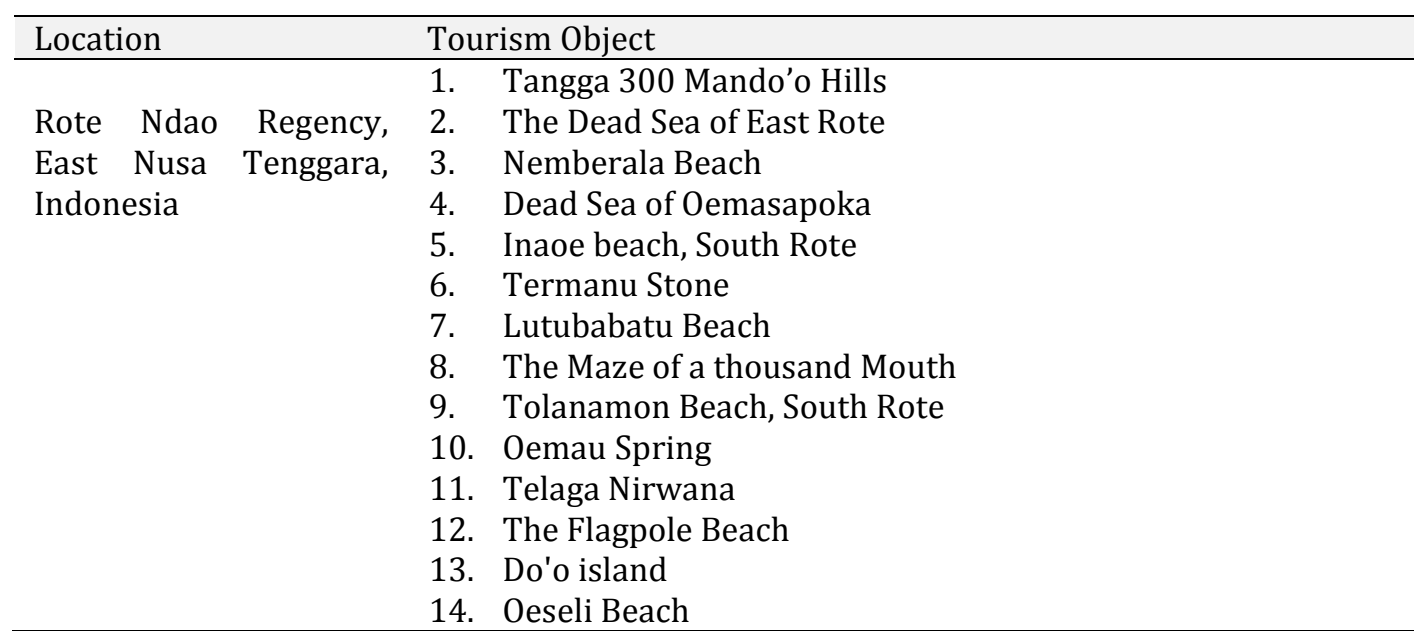

Ndoloe, L. A., \& Rumlaklak, N. D. (2018). Application design in determining the shortest route using tabu search algorithm. International Journal of Physical Sciences and Engineering, 2(3), 77-91. https://doi.org/10.29332/ijpse.v2n3.233 


\begin{tabular}{l} 
15. The Natural Fortress of Laviti Beach \\
16. Seed Resort \\
17. T-Land Resort \\
18. Nemberala Beach Resort \\
19. Narrow Joglo House \\
20. Kakak village \\
21. Relaxing Villa of Rote Island \\
22. Centre of Ikat Janur Kuning \\
23. Centre of Ikat Della \\
\hline
\end{tabular}

The user of the application is a tourist/ prospective tourists who travel to the attractions of Rote Ndao Regency. The applications can be visited at http://wisata-rote.rrums.com page. The pages of the website are shown in the following Figures.

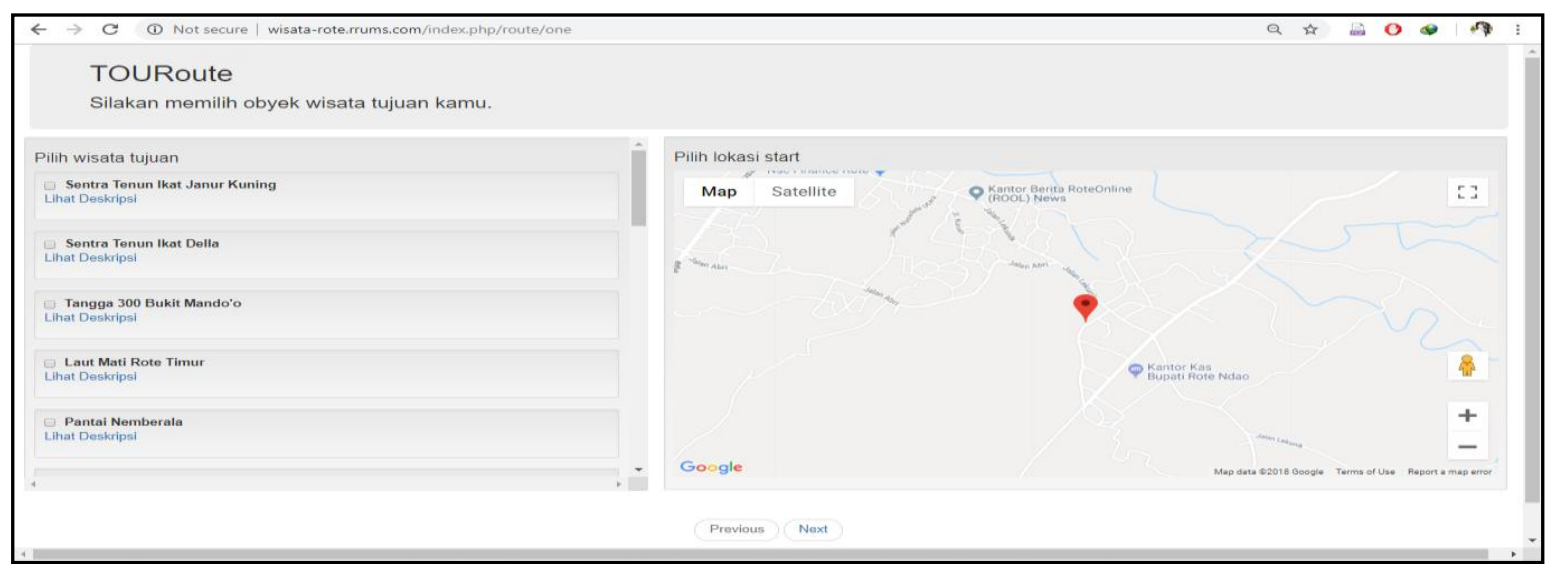

Figure 7. Main page

On the main page, the user selects the attraction to be visited and determine the starting location. There is also additional information available in each option of a tourist destination in the program. The user can also choose "View Description" of the sights she/he wants to see. Description of sights can be seen in Figure 8.

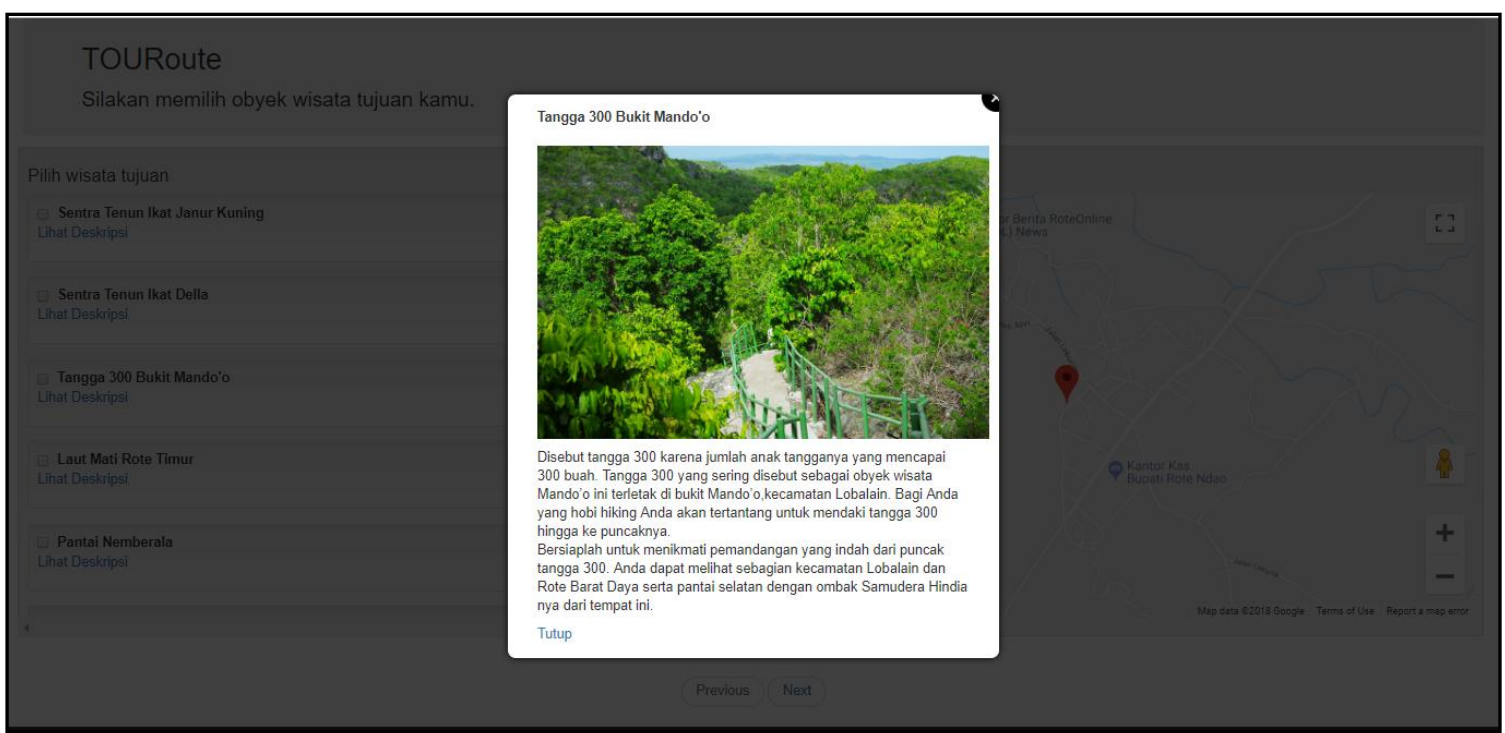

Figure 8. Description of Tourism Attractions' Page 
After choosing the destination location and starting point, the user has to choose the Next button to continue to the page that will inform the selected attractions and locations of the starting and finishing point. It can be seen in the following figure 9.

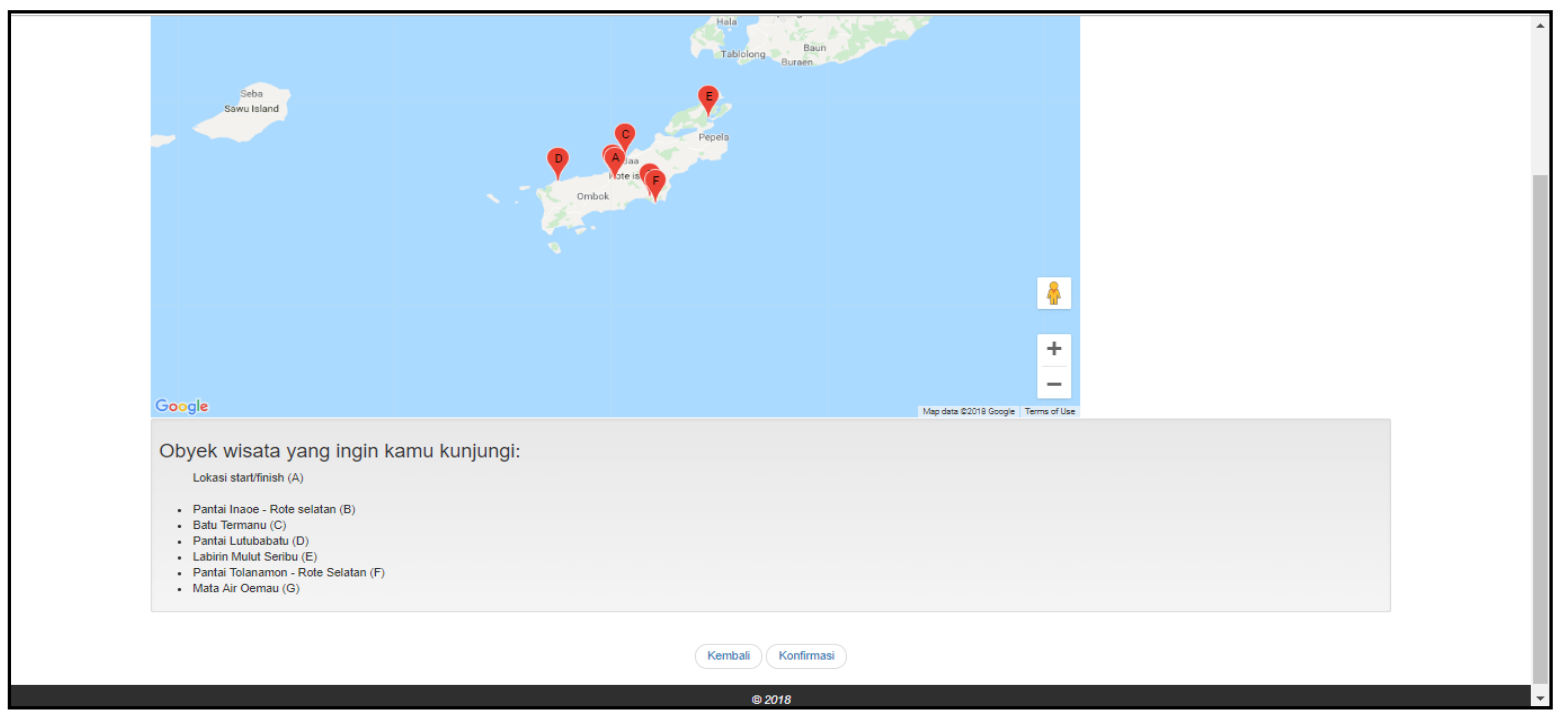

Figure 9. Starting /finishing location information and the selection of tour destinations

If the information displayed is in accordance with the tourists' choice, then the tourists, in this case, the user, can select the confirmation button to proceed with the searching process. This is the way to get the shortest route algorithm with tabu search. The shortest distance and route page can be seen in Figure 10. It contains information about the best route, the location of each tourist attraction, and distance of tour destinations from the starting point to the finishing point.

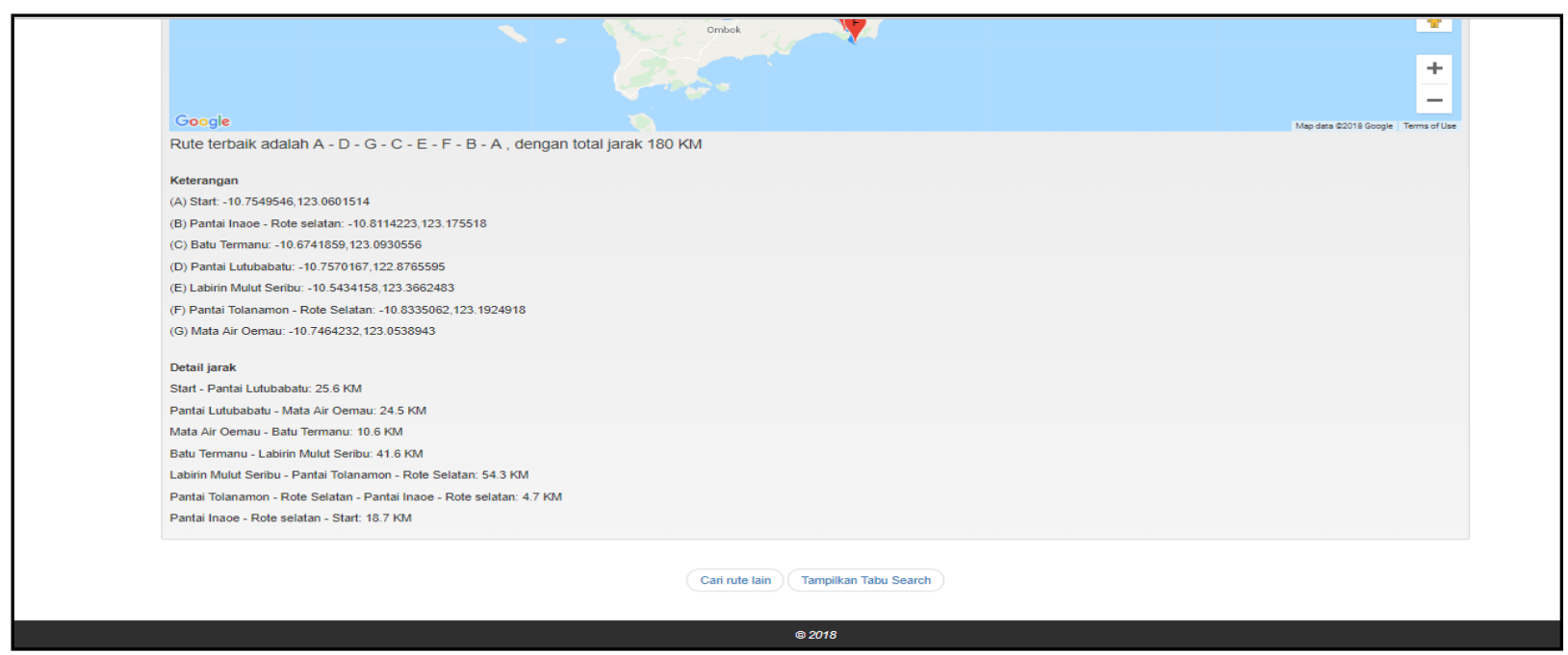

Figure 10. The shortest route

Next, Following are tables that describe data and results of 10 cases with variations of the point, and the number of different destinations.

Ndoloe, L. A., \& Rumlaklak, N. D. (2018). Application design in determining the shortest route using tabu search algorithm. International Journal of Physical Sciences and Engineering, 2(3), 77-91. https://doi.org/10.29332/ijpse.v2n3.233 
Table 4

Tourism Places Data

\begin{tabular}{lll}
\hline Tourism Object & Lattitude & Longitude \\
\hline 1. Tangga 300 Mando'o Hills & -10.8504094 & 123.0718899 \\
2. The Dead Sea of East Rote & -10.5438093 & 123.3194035 \\
3. Nemberala Beach & -10.8899680 & 122.8204211 \\
4. Dead Sea of Oemasapoka & -10.5194231 & 123.3001147 \\
5. Inaoe beach, South Rote & -10.8114223 & 123.175518 \\
6. Termanu Stone & -10.6741859 & 123.0930556 \\
7. Lutubabatu Beach & -10.7570167 & 122.8765595 \\
8. The Maze of a thousand Mouth & -10.5434158 & 123.3662483 \\
9. Tolanamon Beach, South Rote & -10.8335062 & 123.1924918 \\
10. Oemau Spring & -10.7464232 & 123.0538943 \\
11. Telaga Nirwana & -10.9147468 & 122.9087239 \\
12. The Flagpole Beach & -10.7254147 & 123.0264972 \\
13. Do'o island & -10.8294441 & 122.7306896 \\
14. Oeseli Beach & -10.9137081 & 122.9008649 \\
15. The Natural Fortress of Laviti Beach & -10.6869226 & 122.8350816 \\
16. Seed Resort & -10.8998340 & 122.8200643 \\
17. T-Land Resort & -10.8875260 & 122.8217103 \\
18. Nemberala Beach Resort & -10.8913159 & 122.8195792 \\
19. Narrow Joglo House & -10.9071100 & 122.8207201 \\
20. Kakak village & -10.8733236 & 122.8283946 \\
21. Relaxing Villa of Rote Island & -10.8908054 & 122.8198245 \\
22. Centre of Ikat Janur Kuning & -10.7300357 & 123.0399242 \\
23. Centre of Ikat Della & -10.8909466 & 122.8105389 \\
\hline
\end{tabular}

Table 5

The Results of the Shortest Route Algorithm with Tabu Search

\begin{tabular}{|c|c|c|}
\hline No. & Location & $\begin{array}{l}\text { The Results of Tabu Search } \\
\text { Algorithm }\end{array}$ \\
\hline 1 & $\begin{array}{l}\text { Start:-10.756978345434245, 123.06289798203125- } \\
\text { Oemau Springs: } 1.7 \mathrm{KM} \\
\text { Spring Oemau- Termanu Stone 10.6 KM } \\
\text { Termanu Stone - Oemasapoka Dead Sea: } 49.9 \mathrm{KM} \\
\text { Oemasapoka Dead Sea - Inaoe Beach: } 60.1 \mathrm{KM} \\
\text { Inaoe Beach-Tangga } 300 \text { of Mandoo Hill: } 20.3 \mathrm{KM} \\
\text { Tangga } 300 \text { Mandoo Hill - Lutubabatu Beach: } 30.9 \mathrm{KM} \\
\text { Lutubabatu Beach-Start: } 25.7 \mathrm{KM}\end{array}$ & $\begin{array}{l}\text { Results: } \\
\text { The best route: AGECDBFA } \\
\text { Distance }(\mathrm{km}): 199.2 \\
\text { Found at iteration: } 2 \\
\text { Finished in time: } \\
0.23589396476746 \text { microsecond }\end{array}$ \\
\hline 2 & $\begin{array}{l}\text { (A) Start:-10.7549546, } 123.0601514 \text { - Laviti Beach of } \\
\text { Natural Fortress: } 28.1 \mathrm{KM} \\
\text { Laviti Beach of Natural Fortress - Doo Island: } 0 \mathrm{KM} \\
\text { Doo Island - Kakak Village: } 0 \mathrm{KM} \\
\text { Kakak Village - T-Land Resort: } 2.7 \mathrm{KM} \\
\text { T-Land Resort-Nemberala Beach Resort: } 0.9 \mathrm{KM} \\
\text { Nemberala Beach Resort-Seed Resort: } 1.4 \mathrm{KM} \\
\text { Seed Resort-Narrow Joglo House: } 1 \mathrm{KM} \\
\text { Narrow Joglo House-Beach Oeseli: } 14.1 \mathrm{KM} \\
\text { Oeseli Beach-Start: } 32.5 \mathrm{KM}\end{array}$ & $\begin{array}{l}\text { Results: } \\
\text { The best route: ADBIFGEHCA } \\
\text { Distance (km): } 80.7 \\
\text { Found at iteration: } 4 \\
\text { Finished in time: } \\
0.0043570995330811 \text { microsecond }\end{array}$ \\
\hline
\end{tabular}


3 (A) Start:-10.7549546, 123.0601514-Lutubabatu Beach: 25.6 KM

Lutubabatu Beach- Spring Oemau: 24.5 KM

Spring Oemau- Termanu Stone 10.6 KM

Termanu Stone- Labirin Mulut Seribu: 41.6 KM

Labirin Mulut Seribu -Tolanamon Beach: 54.3 KM

Tolanamon Beach - Inaoe Beach: 4.7 KM

Inaoe Beach-Start: 18.7 KM

4 (A) Start:-10.7549546, 123.0601514- Central of Ikat Janur Kuning: $4.1 \mathrm{KM}$

Central of Ikat Janur Kuning - Labirin Mulut Seribu: $51.9 \mathrm{KM}$

Labirin Mulut Seribu -Tolanamon Beach: 54.3 KM

Tolanamon Beach - Tangga 300 Mandoo Hill: $24.8 \mathrm{KM}$

Tangga 300 Mandoo Hill - Centre of Della Ikat: $34.1 \mathrm{KM}$

Centre of Della Ikat - Lutubabatu Beach: 23.6 KM

Lutubabatu Beach-Start: 25.6 KM

5 (A) Start:-10.7549546, 123.0601514- Natural Fortress Laviti Beach: $28.1 \mathrm{KM}$

Laviti Beach of Natural Fortress - Doo Island: 0 KM

Doo Island - Kakak Village: $0 \mathrm{KM}$

Kakak Village - T-Land Resort: 2.7 KM

T-Land Resort-Nemberala Beach Resort: $0.9 \mathrm{KM}$

Nemberala Beach Resort-Narrow Joglo House: $2.1 \mathrm{KM}$

Narrow Joglo House-Beach Oeseli: 14.1 KM

Oeseli Beach-Start: 32.5 KM

6

) Start:-10.751897875426277, 123.05281287613525-

Lutubabatu Beach: 24.1 KM

Lutubabatu Beach- Oeseli Beach: 29.1 KM

Oeseli Beach -Telaga Nirwana: 0.7 KM

Telaga Nirwana - Flagpole Beach: $34 \mathrm{KM}$

Flagpole Beach -The Natural Fortress of Laviti Beach:

$27.4 \mathrm{KM}$

Natural Fortress of Laviti Beach - Termanu Beach 32.5

KM

Termanu Stone- Labirin Mulut Seribu: 41.6 KM

Labirin Mulut Seribu -Tolanamon Beach: 54.3 KM

Tolanamon Beach -Start: 24.4 KM

7 A) Start:-10.7549546, 123.0601514 - Central of Ikat

Janur Kuning: $4.1 \mathrm{KM}$

Central of Ikat Janur Kuning - Inaoe beach: $22.5 \mathrm{KM}$

Inaoe Beach-Tangga 300 of Mandoo Hill: $20.3 \mathrm{KM}$

Tangga 300 Mandoo Hill - Centre of Della Ikat: $34.1 \mathrm{KM}$

Central Ikat of Della - Nemberala Beach: 0 KM

Nemberala Beach - Lutubabatu Beach: 23.6 KM

Lutubabatu beach - Termanu Stone 35.1 KM

Termanu Stone- Labirin Mulut Seribu: 41.6 KM

Labirin Mulut Seribu - Dead Sea of Oemasapoka: 20.8
Results:

The best route: ADGCEFBA

Distance $(\mathrm{km}): 180$

Found at iteration: 9

Finished in time: 0.1948401927948

microsecond

Results:

The best route: ABFGDCEA

Distance (km): 218.4

Found at iteration: 2

Finished in time:

0.10989499092102 microsecond

Results:

The best route: ADBHEFGCA

Distance (km): 80.4

Found at iteration: 4

Finished in time:

0.0031578540802002 microsecond

Results:

The best route: ACHFGIBDEA

Distance (km): 268.1

Found at iteration: 11 Finished in

time: 0.0042121410369873

microsecond

Results:

The best route: ABHDCFJIKGEA

Distance (km): 268.6

Found at iteration: 48

Finished in time:

0.017498970031738 microsecond

Ndoloe, L. A., \& Rumlaklak, N. D. (2018). Application design in determining the shortest route using tabu search algorithm. International Journal of Physical Sciences and Engineering, 2(3), 77-91. https://doi.org/10.29332/ijpse.v2n3.233 
KM

Dead Sea of Oemasapoka - Dead Sea of East Rote: 12.9

KM

The Dead Sea of East Rote - Start: 53.6 KM

8 (A) Start:-10.7549546, 123.0601514-Oemau Springs: $1.4 \mathrm{KM}$

Spring Oemau- Termanu Stone 10.6 KM

Stone Natural Fortresses Termanu Laviti Beach: 32.5 KM

Natural Fortress of Laviti Beach- Flagpole Beach: 27.4 KM

Flagpole Beach- Inaoe Beach: 24.5 KM

Inaoe Beach-Tangga 300 of Mandoo Hill: $20.3 \mathrm{KM}$

Tangga 300 Mandoo Hill -Telaga Nirwana: 27.3 KM

Telaga Nirwana - Oeseli Beach: 0.7 KM

Oeseli Beach- Nemberala Beach: 16.1 KM

Nemberala Beach -Dead Sea of East Rote: 89.7 KM

The Dead Sea of East Rote - Dead Sea of Oemasapoka: $12.9 \mathrm{KM}$

Dead Sea of Oemasapoka-Start: $62.3 \mathrm{KM}$

9 (A) Start:-10.7549546, 123.0601514-Oemau Springs: 1.4 KM

Spring Oemau- Termanu Stone 10.6 KM

Termanu Stone - Ikat Janur Kuning: $9.8 \mathrm{KM}$

Central of Ikat Janur Kuning -Tolanamon Beach 27 KM

Tolanamon Beach - Inaoe Beach: 4.7 KM

Inaoe Beach-Tangga 300 of Mandoo Hill: $20.3 \mathrm{KM}$

Tangga 300 Mandoo Hill -Telaga Nirwana: 27.3 KM

Telaga Nirwana - Central of Ikat Della: 16.4 KM

Central Ikat of Della - Nemberala Beach: $0 \mathrm{KM}$

Nemberala Beach - Lutubabatu Beach: 23.6 KM

Lutubabatu Beach - Labirin Mulut Seribu: 77.1 KM

Labirin Mulut Seribu - Dead Sea of Oemasapoka: 20.8

KM

Dead Sea of Oemasapoka - Dead Sea of East Rote: 12.9

KM

The Dead Sea of East Rote - Start: 53.6 KM

10 Start:-10.7549546, 123.0601514-Oemau Springs: 1.4 KM

Spring Oemau- Termanu Stone 10.6 KM

Termanu Stone - Ikat Janur Kuning: 9.8 KM

Central of Ikat Janur Kuning -Tolanamon Beach 27 KM

Tolanamon Beach - Inaoe Beach: 4.7 KM

Inaoe Beach-Tangga 300 of Mandoo Hill: $20.3 \mathrm{KM}$

Tangga 300 Mandoo Hill - Oeseli Beach: 27.1 KM

Oeseli Beach -Central of Ikat Della: 16.1 KM

Central Ikat of Della - Nemberala Beach: 0 KM

Nemberala Beach - Lutubabatu Beach: 23.6 KM

Lutubabatu Beach - Labirin Mulut Seribu: 77.1 KM

Labirin Mulut Seribu - Dead Sea of Oemasapoka: 20.8
Results:

The best route: AHGLJFBIKDCEA

Distance (km): 325.7

Found at iteration: 4

Finished in time:

0.0098788738250732 microsecond

Results:

The best route: AMIBLHDNCFJKGEA

Distance (km): 305.5

Found at iteration: 5

Finished in time:

0.015729904174805 microsecond

Results:

The best route: AMIBLHDNCFJKGEA

Distance $(\mathrm{km}): 305$

Found at iteration: 5

Finished in time:

0.01583194732666 microsecond 
KM

Dead Sea of Oemasapoka - Dead Sea of East Rote: 12.9

KM

The Dead Sea of East Rote - Start: 53.6 KM

The cases shown in table 4 and table 5 were running use algorithm of tabu search with a maximum of 50 iterations. On the 10 cases above that obtained with the algorithm of tabu search, it can be seen the result featuring the best route or the shortest distance to reach a tourism destination. The results that based on our examination about the best route are recommended for travelers/tourists who want to visit prospective tourism objects in Rote Island, Indonesia.

\section{Conclusion}

Based on a series of research stages that have been conducted, it can be concluded that the application of the travel route that has been built can be recommended to those who need to find the best route for tourists in the Regency Rote Ndao Regency. In another side, as we have examined the application in Rote Ndao Regency, Indonesia, we stated that Tabu search algorithm can be used for solving the shortest route search. This algorithm shows the time resolution that relatively short for a selection on many tourist destinations.

Acknowledgments

This work was supported by the Research Fund provided by Politeknik Negeri Kupang.

Ndoloe, L. A., \& Rumlaklak, N. D. (2018). Application design in determining the shortest route using tabu search algorithm. International Journal of Physical Sciences and Engineering, 2(3), 77-91. 


\section{References}

Bajeh, A. O., \& Abolarinwa, K. O. (2011). Optimization: a comparative study of genetic and tabu search algorithms. International Journal of Computer Applications (IJCA), 31(5).

Chelouah, R., \& Siarry, P. (2000). Tabu search applied to global optimization. European journal of operational research, 123(2), 256-270. https://doi.org/10.1016/S0377-2217(99)00255-6

Fard, M. K., \& Akbari, M. R. (2013). A hybrid tabu search algorithm for the vehicle routing problem with simultaneous pickup and delivery and maximum tour time length. African Journal of Business Management, 7(11), 801-810.

Kusumadewi, S., \& Purnomo, H. (2005). Penyelesaian masalah optimasi dengan teknik-teknik heuristik. Yogyakarta: Graha Ilmu.

Manafe, J., Setyorini, T., \& Alang, Y. (2018). Influence of implementation on mix promotion model strategy towards tourist visitation in Indonesia. International Research Journal of Management, IT and Social Sciences, 5(6), 26-39. https://doi.org/10.21744/irjmis.v5n6.334

Munir, R. (2010). Matematika Diskrit.

Sarmady, S. (2012). An Investigation on Tabu Search Parameters. School of Computer Sciences, Universiti Sains Malaysia, 11800.

Suyanto, A. O. (2010). Deterministik atau Probabilitik. Yogyakarta: Graha Ilmu.

Varita, I., Setyawati, O., \& Rahadi, D. (2014). Pencarian Jalur Tercepat Rute Perjalanan Wisata Dengan Algoritma Tabu Search. Jurnal EECCIS, 7(2), 185-190. 


\section{Biography of Authors}

\begin{tabular}{|l|l||}
\hline Lita Alfriany Ndoloe is a lecturer of Politeknik Negeri Kupang, East Nusa Tenggara, \\
Indonesia. She is interested in Information Technology. Besides teaching, she is \\
active in conducting researches related to information technology as well as other \\
computer sciences. \\
Email: litandolu83@gmail.com
\end{tabular}

Ndoloe, L. A., \& Rumlaklak, N. D. (2018). Application design in determining the shortest route using tabu search algorithm. International Journal of Physical Sciences and Engineering, 2(3), 77-91. https://doi.org/10.29332/ijpse.v2n3.233 